10-1992

\title{
ARCHBISHOP MANNING AND THE KULTURKAMPF
}

Jeffrey P. von Arx

Fairfield University, president@fairfield.edu

Follow this and additional works at: https://digitalcommons.fairfield.edu/history-facultypubs

Copyright 1992 Catholic Record Society http://www.catholicrecordsociety.co.uk Recusant History http://www.catholicrecordsociety.co.uk/recusant-history

\section{Peer Reviewed}

\section{Repository Citation}

von Arx, Jeffrey P., "ARCHBISHOP MANNING AND THE KULTURKAMPF" (1992). History Faculty

Publications. 34.

https://digitalcommons.fairfield.edu/history-facultypubs/34

\section{Published Citation}

von Arx S.J., Jeffrey P. "ARCHBISHOP MANNING AND THE KULTURKAMPF". Recusant History; Oct1992, Vol. 21 Issue 2, p254-266, 13p

This item has been accepted for inclusion in DigitalCommons@Fairfield by an authorized administrator of DigitalCommons@Fairfield. It is brought to you by DigitalCommons@Fairfield with permission from the rightsholder(s) and is protected by copyright and/or related rights. You are free to use this item in any way that is permitted by the copyright and related rights legislation that applies to your use. For other uses, you need to obtain permission from the rights-holder(s) directly, unless additional rights are indicated by a Creative Commons license in the record and/or on the work itself. For more information, please contact digitalcommons@fairfield.edu. 


\section{ARCHBISHOP MANNING AND THE KULTURKAMPF}

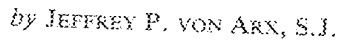

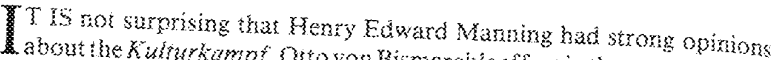

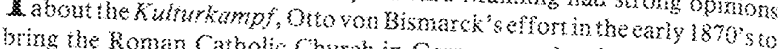

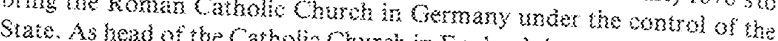

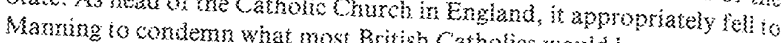
persecution of their Chum in the now Manning knew nersonaly she be new German Frmpire. Noreover Bismasch krom personaly the bishogs involved in the sonflict with

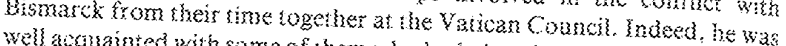

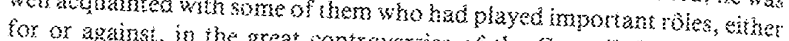
definition of $\mathrm{p}$ and the great controwarsies of the Comancis that led to the

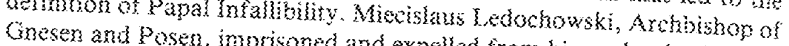
government in 3874 , has and and expelsed from his see by the Gemman

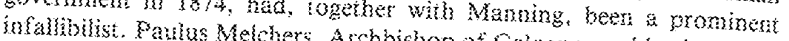

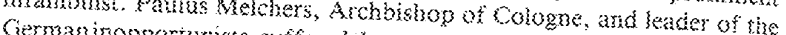

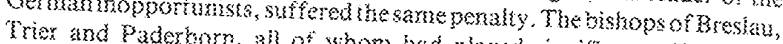

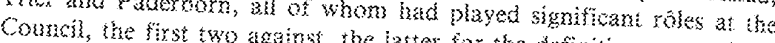

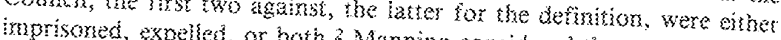

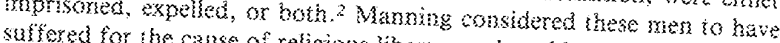

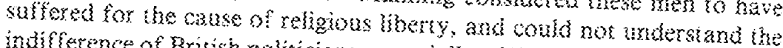

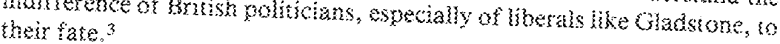

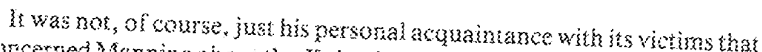
concerred Manning about the Kuhurkampf. The wrovisons of the various kaws introduce under the mame of the grassian Minister of public

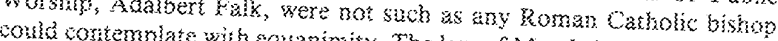

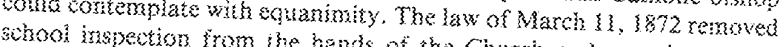

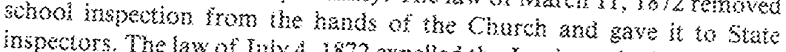

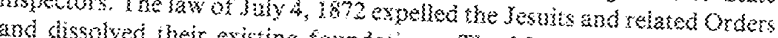

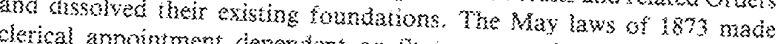

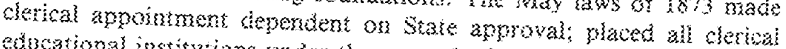

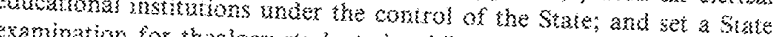
examination for theology studersts in phikosopiny, history and Gerrnas:

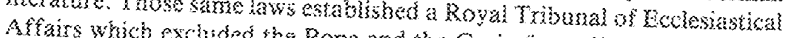

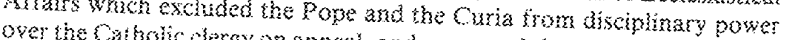
over the fatholic dergy on appeat, and arrogated that power to iscel, the

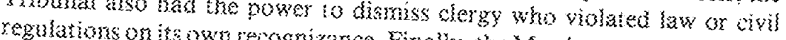
ragulanions on its own recognizance. Finally, the May kass severely linited

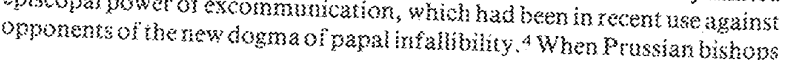

erused and forbade any congeration with the kay kaws, when directors ot

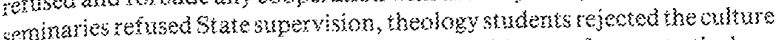

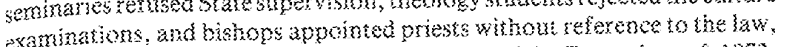

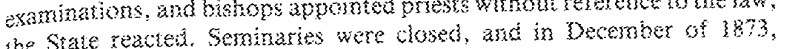

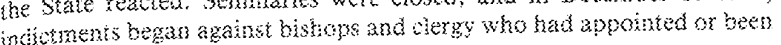
anowined ineagily. 5

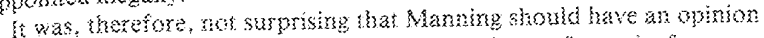

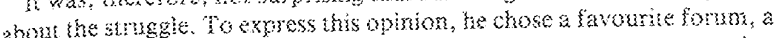

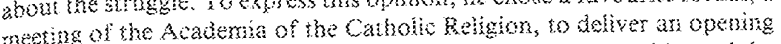

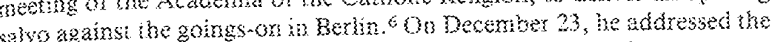

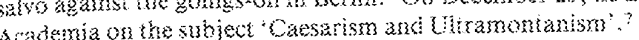

Now' 'Cacsarsm and Uhramontanism' probably gualifies as the mos:

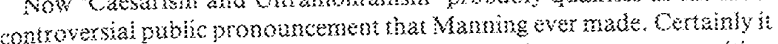
wired un note gesponse som the press thas any other statemest on writing

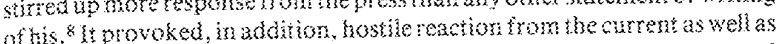
a former prime minister. For Fark Russel, Manning's position represented subjection to a 'despotic and tallibie priesthood, and later that wimter

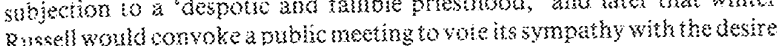
of Germans to be free from papa\} aggsession the addrese was jarty

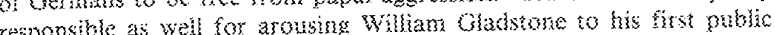

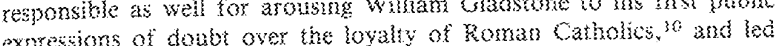

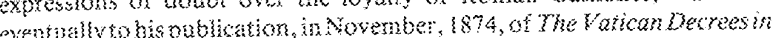
Their Beorng on Civi Alegiance. Minally. "Caesarism and Ultramona.

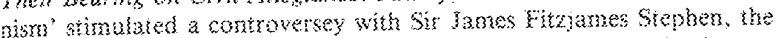
noted jurist, in the pages of the Contemporary kevew. Stephen's own

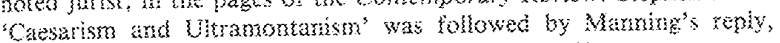
Stenhen's response, and a rinal rejuinder by Manning."

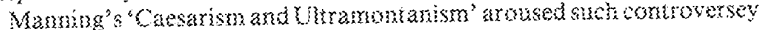
becande it was kaken by his contemporaries to be a statement of the most sxicme abranontane position on the relations of Chuseh and State. "The Times, for example, chamed, to be starled 'to bear the fully developed

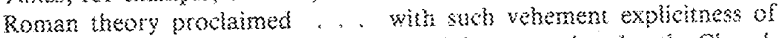

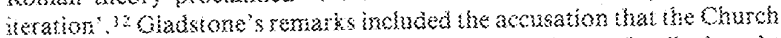

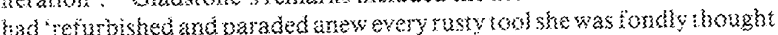

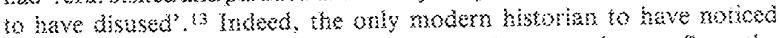

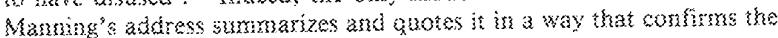

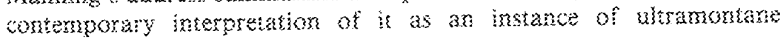
bverstatement. ${ }^{2}$

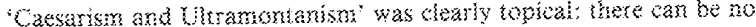

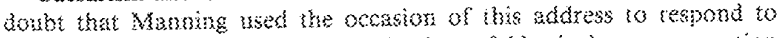
disturbing manifertations of the Kulturkampl. Nor is there any question that it contains the rhetoric of hine koman 'thesis' position: the bury of the State to recognize the Chureh. 3umport is and defer to the Charch's own discernment of its spiritual mission. punt there are ofher dimensions of this important statement by Manninge and of the Gares controversy it angen-

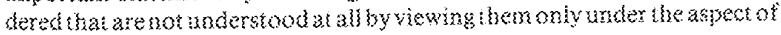
urramomane goilemic. 
'Caesarism and Uhramontanism' and the controveroial artioles that followed noon it areacritioue of modern politicsmospecially is statisn and zathonakssn, in Germany, but also in England. More signisucantly, they represent anotber stage in Mannimg's effor to respond positiviy and

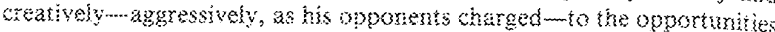

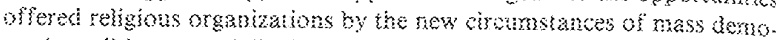
watic polktios, especkally in England. His opponents, kowever, both overestmated and underestimated Manning's nomton if they thanght kis assertiveness in 'Caesarism and Uyramontarism' was aisned at restorng

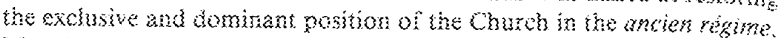

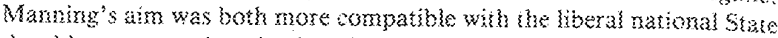

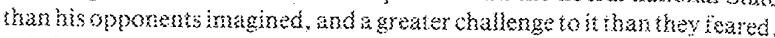

it is signifeant that Manning chose a meting of the Academia of the Cutrobic Roingon as the occasion to castigate the Kulturkampl, it was, we

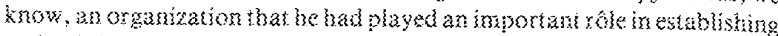
and guding, and one frors which he bad great expectations. In the pant, especialy in the seswions of $1866-67$ and $3868-69$, be had used the privitere

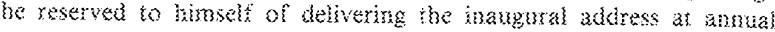
meetings to mathe important statements about the conditon and prospects of religion in England: the conditions and proskects of the Caknote Church, of course, but also, of the Established Charch and the Nonconfor. mists. Otter, he deat with the relatom berwen Chuschand State, but less in theoretical terms than in commentary on the acual comdition of those relations ins conemporary britian. Whally, it is interesting to wote that in

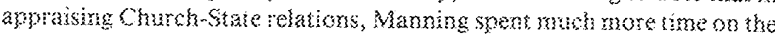

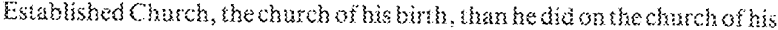

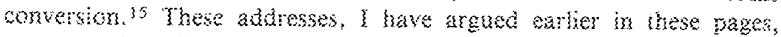
regresented an effort by Manning in the late $\$ 860^{\prime} \mathrm{s}$ to work out a rationale for the collaboration of Catholes with other commited Chistian com

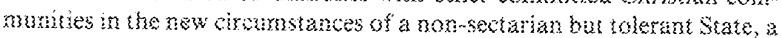

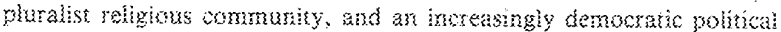
culsure 36

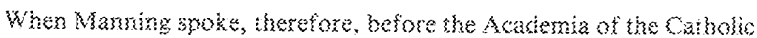

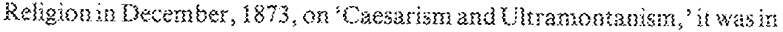

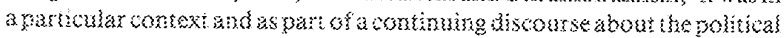

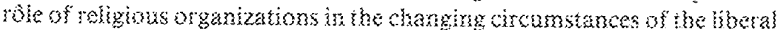
State as is was emerging in Great Brikan.

'That 'Caesarim and Ulramontanism' showdin fact be sed as another

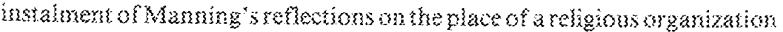
wakhin the liberal State may be seen from what follows: Mammug "s addrew,

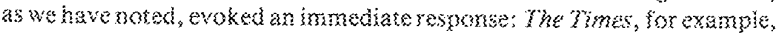

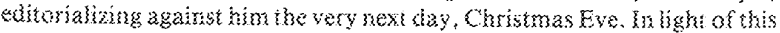
public rasponse, Mamming mubisked the adoress with a preface dated

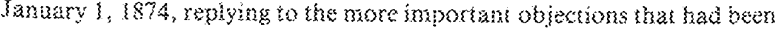

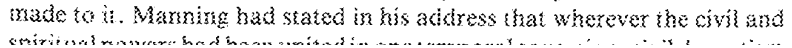

and rebighu gersecution folowed. Crities objected that the condition of

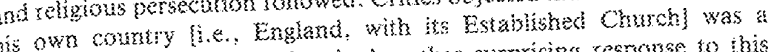
(1) Manming's rather surpresing responge to this

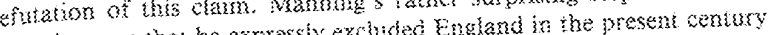

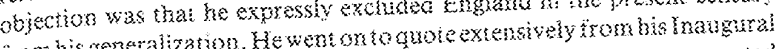

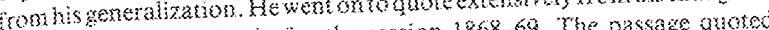

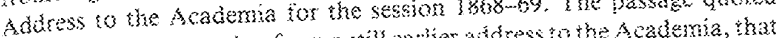

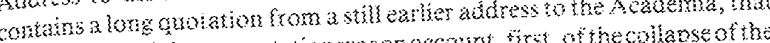

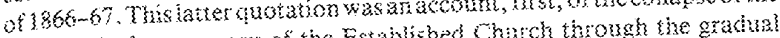

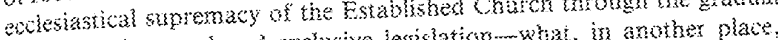
remeal of the jenst and exclusive legistation-what, ish anothe place

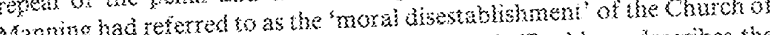

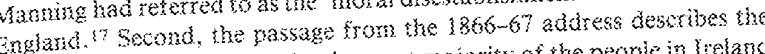
rienion of that subremacy by the great maknty of the people in heland

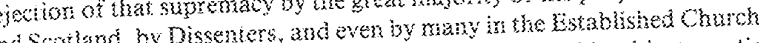

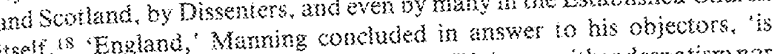

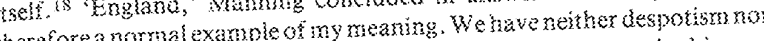
theresoreanormal exanple ot iny we aning. We havene is not united in one persecution, nerson. "19

Fwo important moints mass be nade in rekation ho Nanning 3 treatment

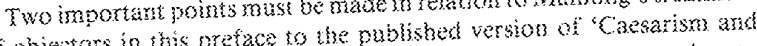

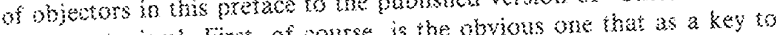

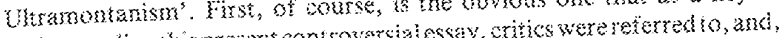

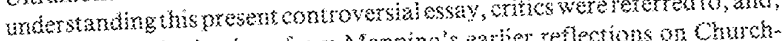

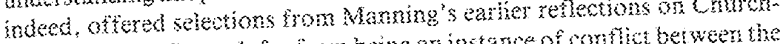

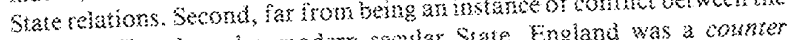

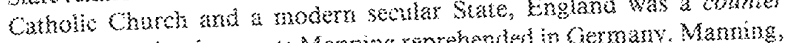
indication to developments Mamming reprehended in Germany. Mansang,

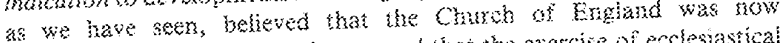

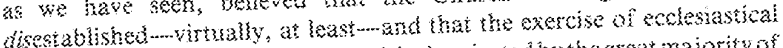

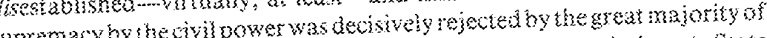

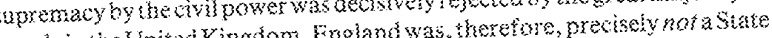

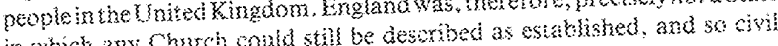

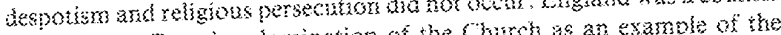

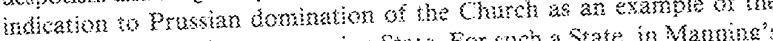

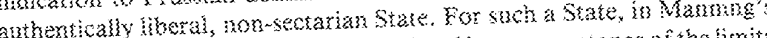

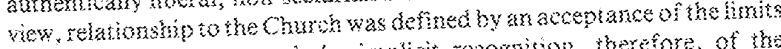

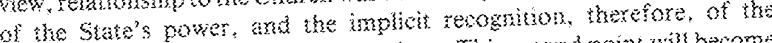

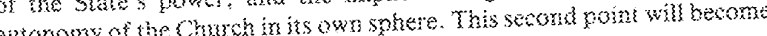

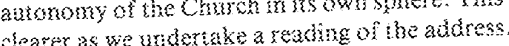

dearer as we underake a rewding of the audress.

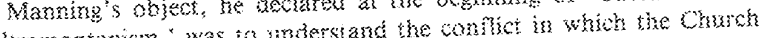

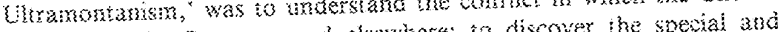

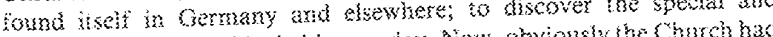

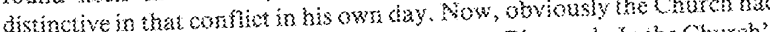

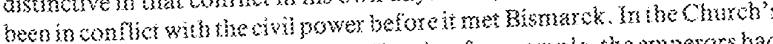

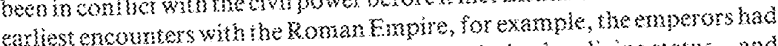

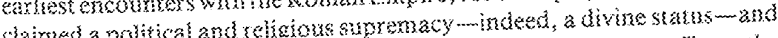

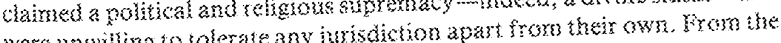




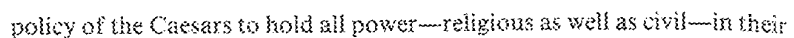

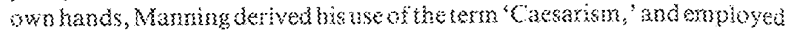

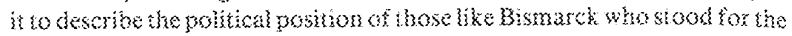
conesuration of sivit and rebigions power in a single political ontity, whether king, at33embly of the people as a whole.

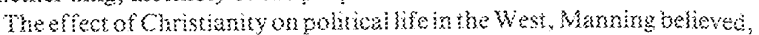

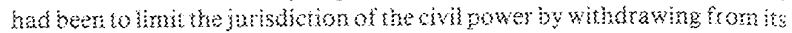

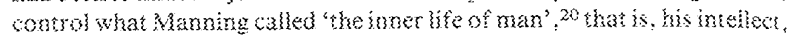

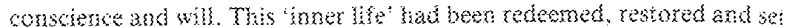
free by God in Christ and sn it was onky Gos or God's chumb that hat

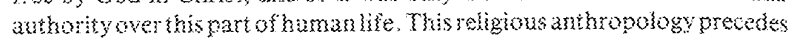
unmediately, and so contextalizes one of the mos controversial bas sogas

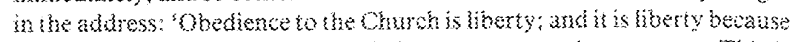
the Charch carrot ers on miskas either rnen or nations. . . This is

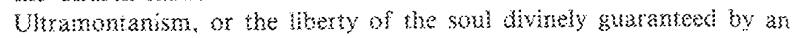

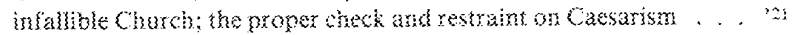

The fiberty of the Churb was not onky lor the sake, however, of the interiox he of the believer. in a brief historical overview of raiations of Church and State in the medieval period. Manning vent on to indicat how he though their encounter had led to deas of theciviluberties of nidividiats

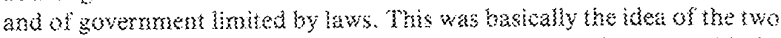
powers, civil andreligious, aach autonomous in its own sykere, but with the clains of the spirtual acoordes precedence and acknowledyed as a restrim on the exercise of crull power.

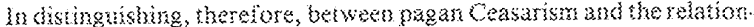
ship of Churb and sute worked ow in the medieval period, among the

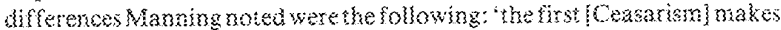
religion an instrument ot deparment of state; the second mates it the Humation of civil power, and he motection of human kiberty. The first treats the Church as subjen to itseb; the second treats all civil power as sabject to God and has law, of which the Church is the guardian and

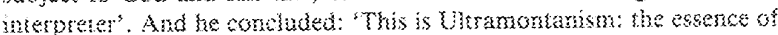

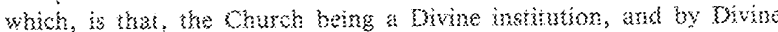

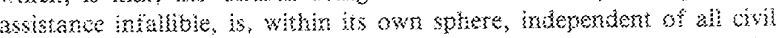
powers; and, as the guardian and interbeter of the bivine law, it is the proner judge of mers and of nations in al things towebing that law in taith arsiz moxids? 22

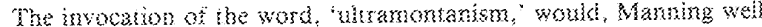
knew, provole misurberstanding and risk dismissal of this casehuly

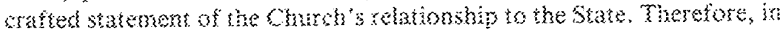
the nex section of his address, be undertoph to show thet what he called

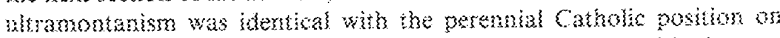

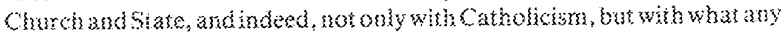
Christian woukd himk on this subject.

Manning believed that kis arament sbout the inovitable relationship

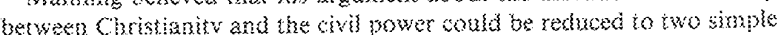

primitich: 3) the separation of the two powers; 2 the subremacy of the niriubl over the civil in all matters xithis its competerse. These two

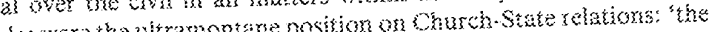

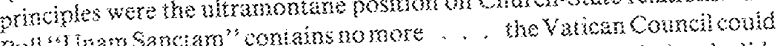

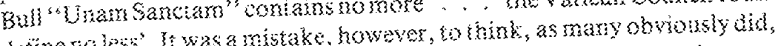

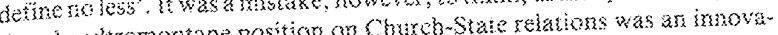

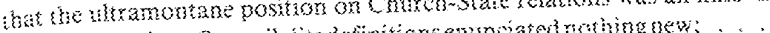

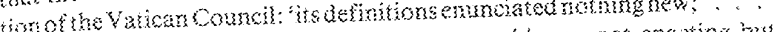

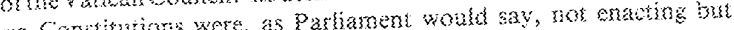

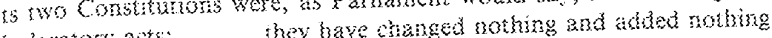

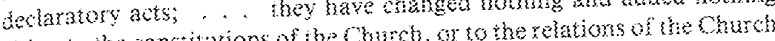
wither bo the constiturions of the Chu

with the civit powers of the woth". 23 whe the of

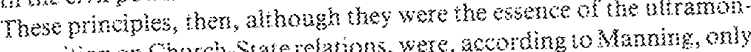

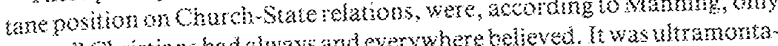

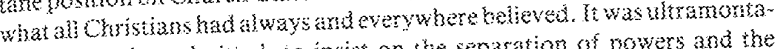
wisn, Manring admitted, 10 insist on the sepasation of fowers and the upremacy of the spirinal power in its own sphere. but it is not Uhtranson-

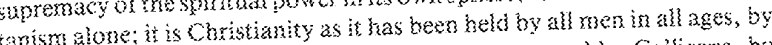

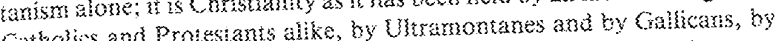
Catholss and Protestants alke, by Uhe Fre Churches of England . .

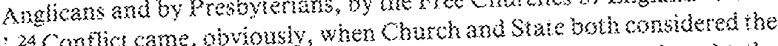

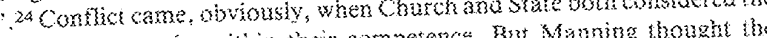
same matter to be whin theis competence. But Manning thougnt the

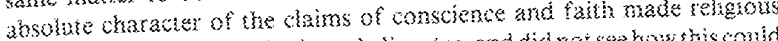

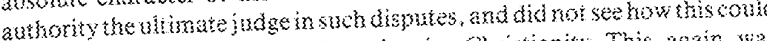
be denied by any Chnstam without derying Chriktantity. This, agan, was all that was clamed by "Unam Sancham, by the Sylabus o: by the Vatican Councia 25

3is imporant to aporeciate the character and reach of the athority

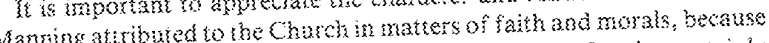

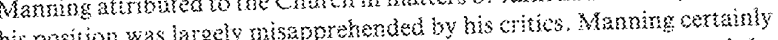

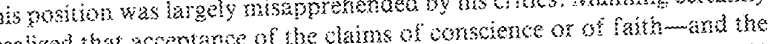

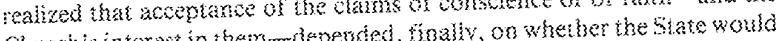

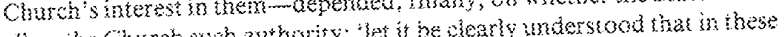

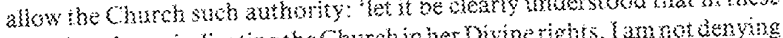

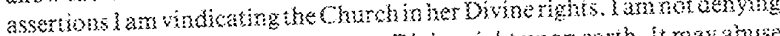

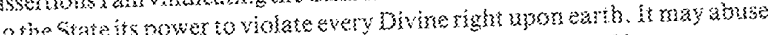

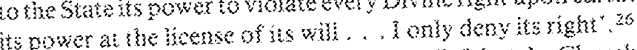

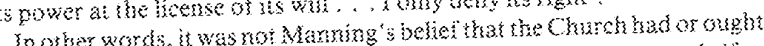

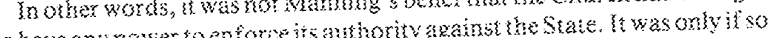

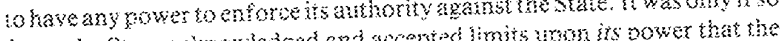

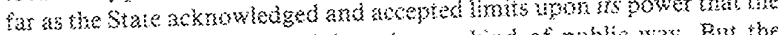

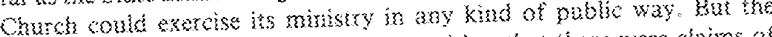

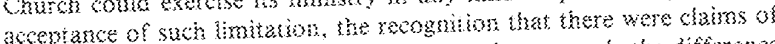

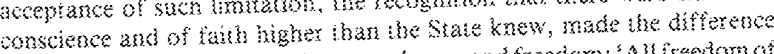

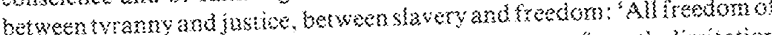

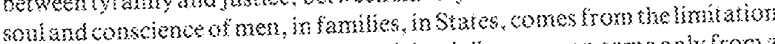

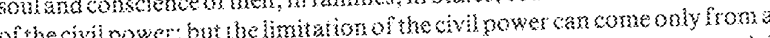

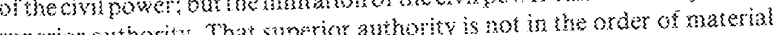

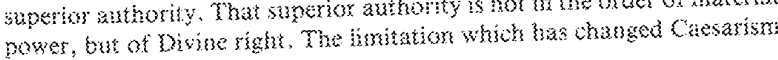


into Christian monatchy is law; and that law, the kaw of Gon, represented,

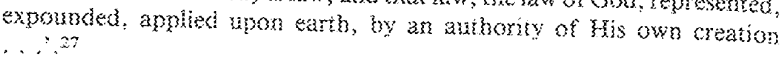

Buring the fistory of Christendom, when for Mamning exterded frost

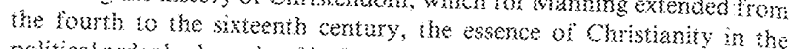
political order kat consicted in the separation of the powers stemporat the

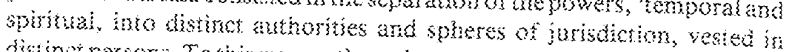
distinct persons. Tothis we owe the order, progress, whisation, and so tar

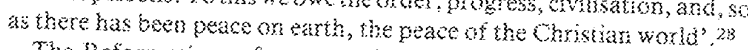

The hetombation, of combse, with is institution of royal supremacy represented from Marning's goint of view theremudesence of Caesatisn: the seurion $k$ on e person of the wo powers which Clristendom had pu asurder. Now what was remarkable so Maning in the soberusen history of prostant natms-particulany of the United Kingdon-was the

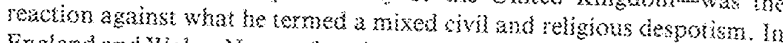

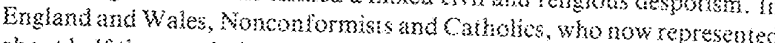

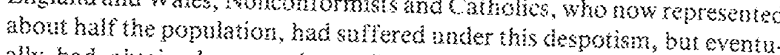

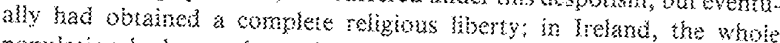
population had recenty attained freedon in this regard. 5 , the whon

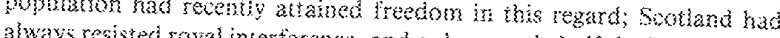
akways registed royal interterence, and mily recenty half the presbyterian popmiaton had broben wht the Established Chusch over the last semname of civil interference in the law of patronage $2 \%$

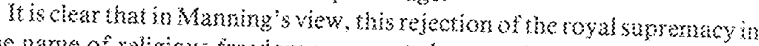

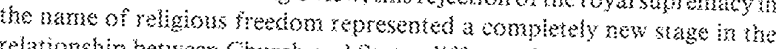

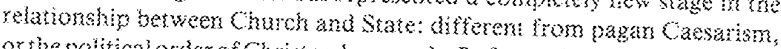
or be poltical order of Chistendorn, or the Reformation royal supramaw, Yowas, in fact, that new stage of the Churebs relationship with the State whose distinctivenews Maming had set ous to diseover at the beginning of
bis ergusiry.

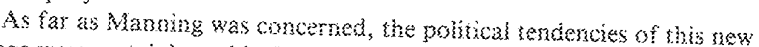
stage were certainly anbivalent as regarded the freedom of the Church. There was, for example, a very widespread opinom in tavour of 'here

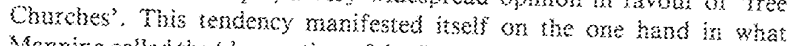

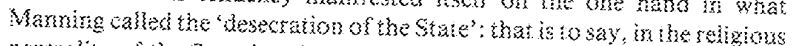

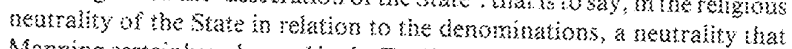

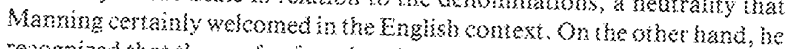

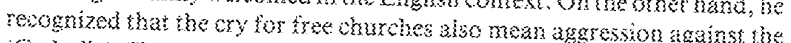

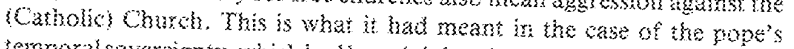
temgora\} sovereignty, which hat hoen 'viokted on the ghes that the civil and spiritual powess ough is be onse nore separated, not as jrovidence had ordaned bitbero, but on he imnossible theory of a fres church in a tres Siate'.30

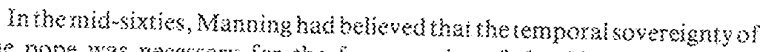
the jope was necessiary for the tree exercise of the Charch's mission

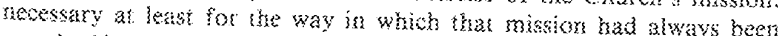

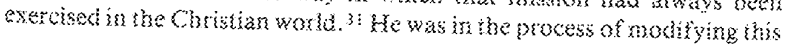

belef, and by 1876 would wrge apon the Vatican an acommodation with the takian government that the Vatican was unwiling to make, 32 Wut what

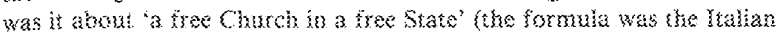

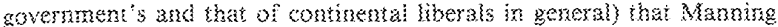
thonglyt so impossible? Kot, certaink, the idea of separation itself, since that was part of his own theory of Church-State relations; not, suresy, the

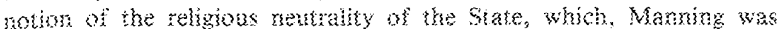
beginumgrothink, operated in the best interests of the Church, certumby in Gritain, tser great colones, and also the Ynited States. What Manning thougut inposible were the practica conbechences of the theory of a free Churot in a free Stake. "The ftalian Kevolution," Mamming observed, "has mut this \{heory\} forwaru as its solution of the religious onflicts of the

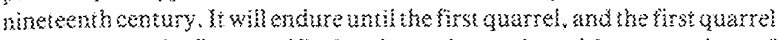

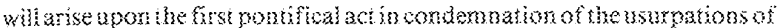
the free State. The supremacy of the divil power will then be kevared to be vital to its freedom?

3t was, tharefore, nether thenotion of separation, nor the prospect of the religious neutaliy of the State hat concerned Manning as be considered ibs new stage in the rektumbin between Chuth and State. But he perceved that the modern reaction against of ficial recognition or establish-

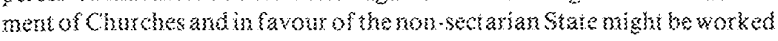
to very abterent purposes, some of them, paradovically, quite inumical to

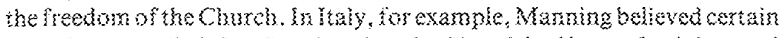

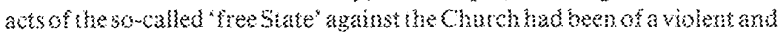
sactiegions character. Even so, he was confidant thathe Catholic faithand instinct at the people wold save ltaly from 33 organized and systematio

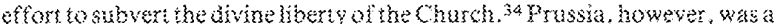
differen story. There, eclesiastical kegislation which claimed to vindicate the rights of the state agains the Charches embodied expicitiy anti-

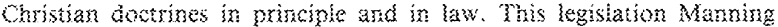
considered "he int between the of royal supremacies of the sixtenth century and the revived $L \& x$ Regia which the antw Christan revolution is premaring for the fature of Eurone'.35

In prusia, theretore, Manming though he recognized the form of a new and distnctively modern Caesarisn. The essence of this modern Chesarism was the assertion 'mot mily ind the State has sungeme gower over the

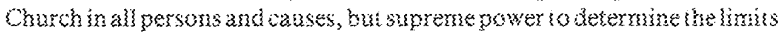

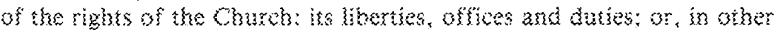
words, that the State on determine, and the Church cannot betemine, what is the authority and commission entrubted 10 it by ins Divine Founders. ${ }^{36}$

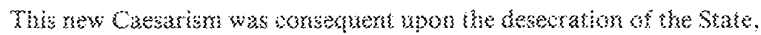

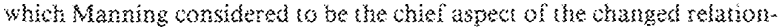
ship between Church and State in the modem word. That desecration, it must be emphizized, was not iself Caesarism, since Englank, which Manning regarded as a desecrated State, was explichly exemper from the 
smpuabon of Caestrism, But that was not to say that Caesarism of the

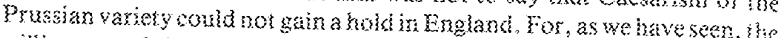

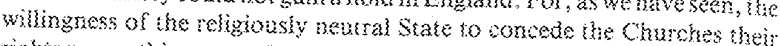

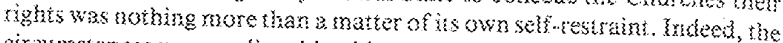

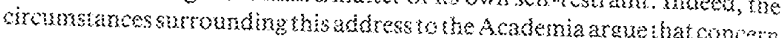

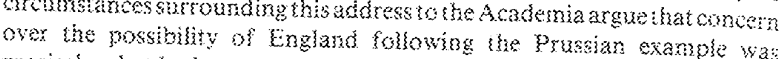

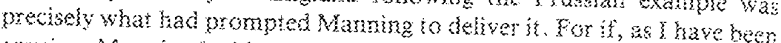

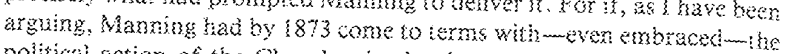
polich action of the Churches in the derotratic environmen of the

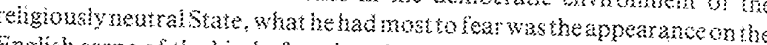
Englisk scene of the kind of statism that was bohisud the Fa\}k laws.

In 'Caesarism and Chtranontanisn,' Manning sted a muber of indications that swoh a sentiment was present in Ergugnd. Fhere was for

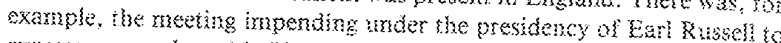

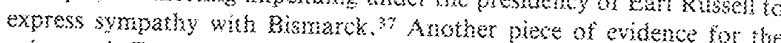

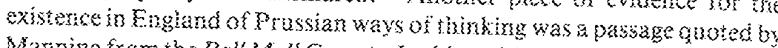

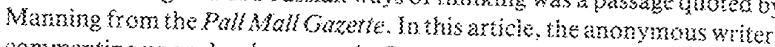
commenting upon developments in Germanxy, turned to k\}e Englis\} scens, and remanked apon a conviction. . sxceedingky powertul [that] bas been and stikl is growizg up, that a ration, as such, is essentially a better thing than

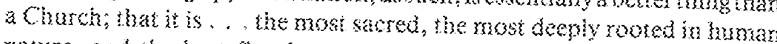

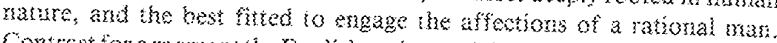

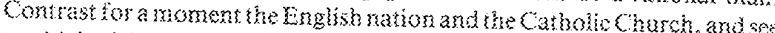

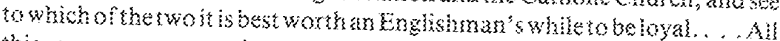
this, we say, jars nations above Churches as objects of affection and byaty. . We houblegard no one as realky loyal to his nation who did not regard it as being to him a higher asz noro sacred object than any Churok whatever'. Mannings's "eshonse was, 'this doctine is revived Y.3garism. 38

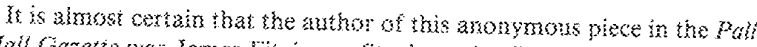
Mall Gazetie was Janes titzjames Stephen, the distinguished jurist ask legal soholat. If that is 30 , Manning, by singling this passage on,

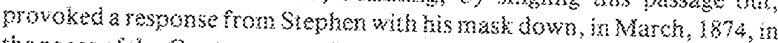
the gages of the Contemporary Review, andintiated a controversy hat ras in the next three issues of that iourna?.

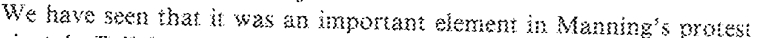

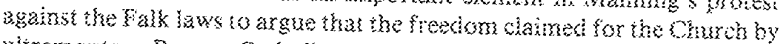
whramontane Roman Catholics was no more than the indapendence from State control of dockne and discipline chimed by every Christian denomi

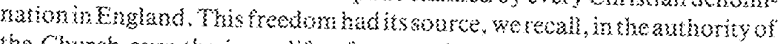

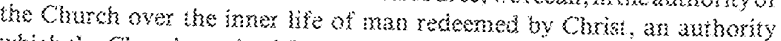
whick the Chusch recived from bon.

Like other cratce of "Cacsarismand Mhamontanimm, Stewhen beleved

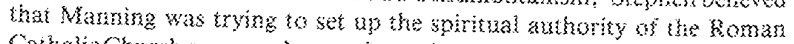

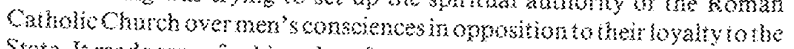

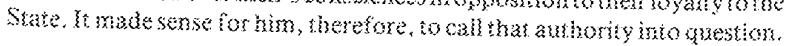

Now Stephen bad the renutation of hatre a powersial and thorough-going

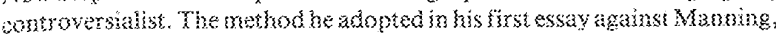

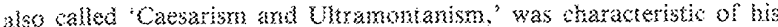

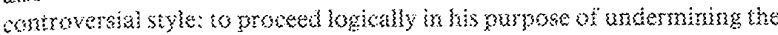

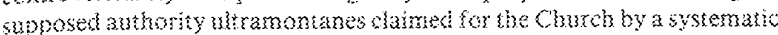

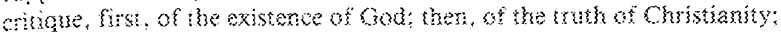

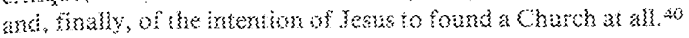

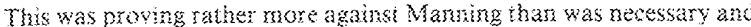
jnvolved Stephem in a mistake of srategy. For it offered Manning the opmortunity of axgealng aganst Stephen 10 other Bnitish Christians on

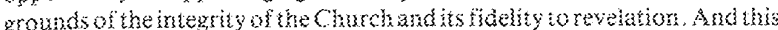
was prewsely what Marning did in his response ko Stophon, "Utramonkanism and Christianity

The anthority that Manning wished to vindicate wä, of course, the authwity of the koma Catholic Cbureb. What was intriguing, bowever,

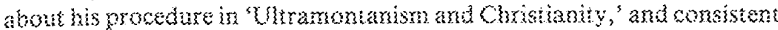
whth earlier treatment of Church-State guebrons, ${ }^{2}$ was the decision to prove his case that the Church is separate and supreme in iss own sphere wibhou any reference al all ko zoman Catholic teaching, but only kn the Evidence of non-Catholic witnesses', 43

kn afl e3say of 34 pages, 22 pages were devoted to ans exposition of the

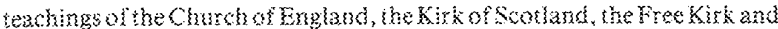
the Fee Churehes of Endusud on the independence and sumpernasy of the

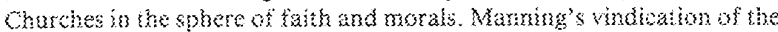
independence of the Chuxch of Fugland in sclation to the crown is as synghatheric a presentation of the integrity any Anglican could have desirest One reaks it with the sense that, on this ocvasion, Marming had refurbiahed arguments whth which he was ased to

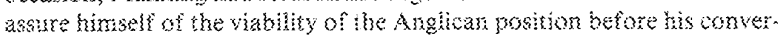
sion. And even though he points ou that the anonomy chained by the

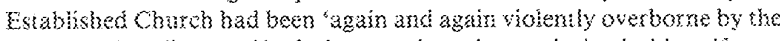

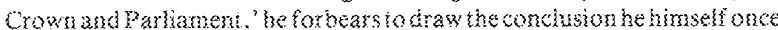
drew from this state of athirs, observing that 'it is not my purpose now to

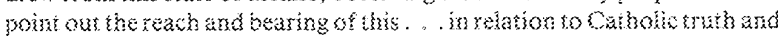
mant $y^{3}, 45$

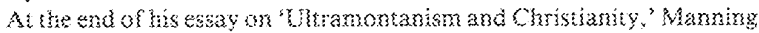

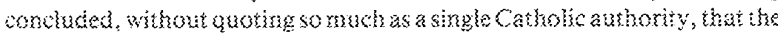
universal witnes of Christianity in Briain was tor the hadependence and treedom of the Church:

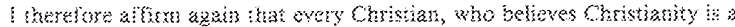

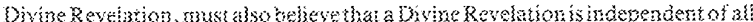

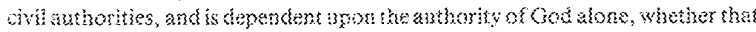

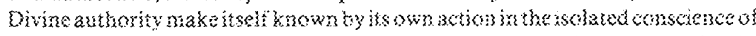

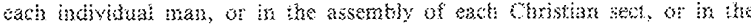

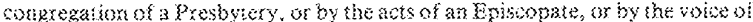

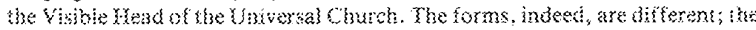

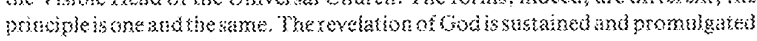




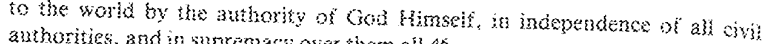
authorities, and in suprenacy over them all, 46

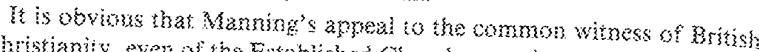

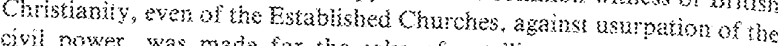
civil power, was made for the sake of a tabng controversing point,

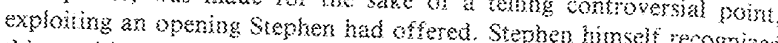

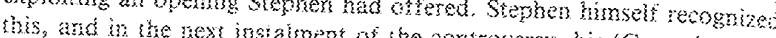
this, and he he nex isatalment of the controversy, his 'Cossanism and

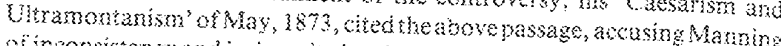

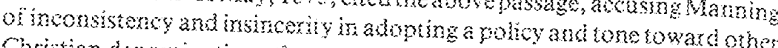

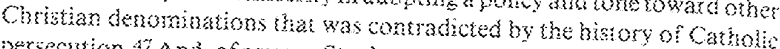

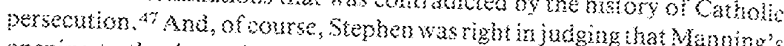
opening to the denominationa was a depanture from Catholic tbeory and practice. But he was whong in thinking it insincere on Manning's part. or made ong ton the sake of polumical or partisan abvandage.

For polernical effectiveness against the llkes of Stepher was by roments

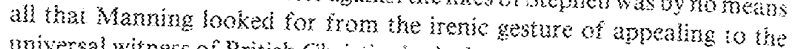

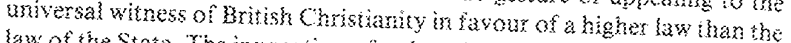
kw of the State. The invocation of a shared wirness to hie freadom of the

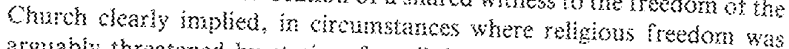
arguably threatened by statisn for all denominations, 3 williggness to mobilize and work together with other Christan denominations on issaes

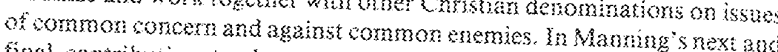

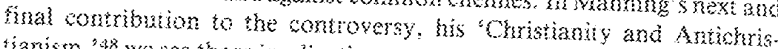

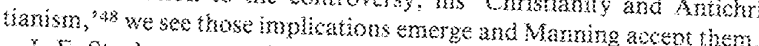

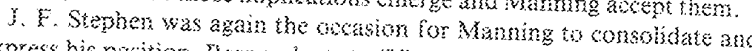

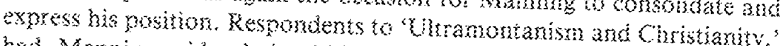

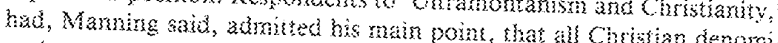
rations, at one time or another, presened hemselves as representins a higher anthority tha the State in their chame on the consciences of mer: at A gainst this claim, Stephen had defended the wropsiton that the mation a higher and more saced object han any Church whatsocver: and is commanded a higher byaly and obedience.

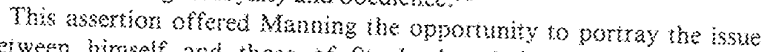
between birstelt and those of Stephen's mind who sugportod the

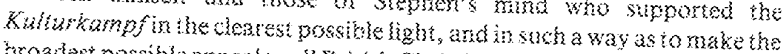

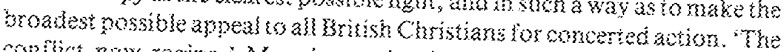

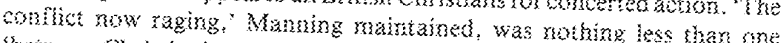

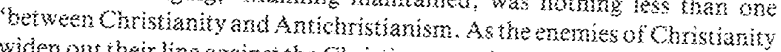

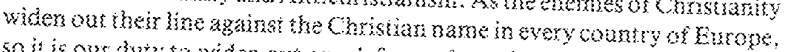

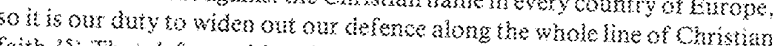

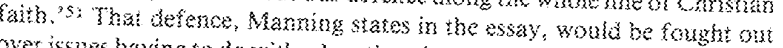

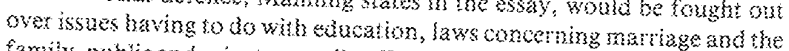

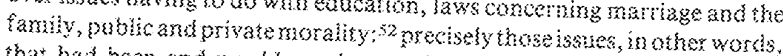
that had been and would contiuse to be of umbst consers not yost to

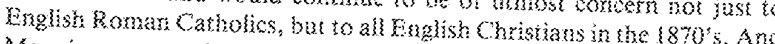
Manning was comvinced that "the people of England would at once ingrust authority over martiage and education ather to Christianity than to Secularian, or Caesarism, of Scepticism, on to a State stripped of the laws and morais of Christianity".s

ha vinkicating the right of the koman Cathohe Church, whether in

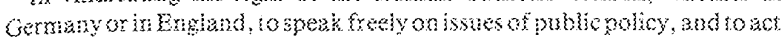

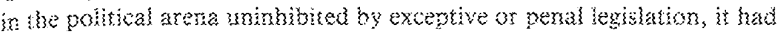
never bees part of Maming's briêt to chaim a privileged position in that

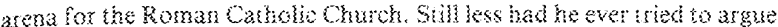

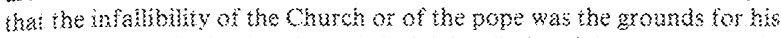

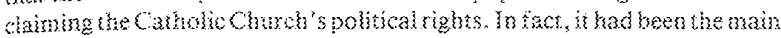
point of his previous exay ("Uhtramonamisn and Chrigtianity") to show that all Christans, whatever the form or constitution of their Chuxch,

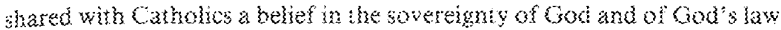
which was their conmon charter for political action. ha Coristianty and

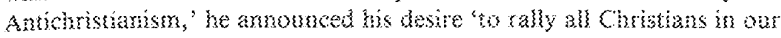

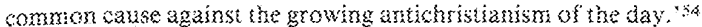

This straggle againstantichristarism as the common enemy of all Gritsh

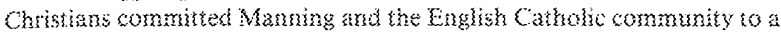
degree of political initative, creativity, activism and collaboration with oher religiousiy-minded peonle organized to polical purposes that was

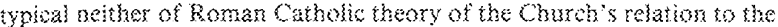
State, nor, centanin, of the pactice, up unth then, of Enghish koman catholics.

\section{NOTES}

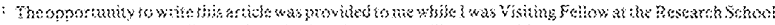

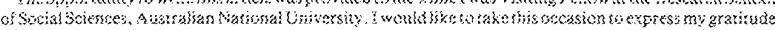

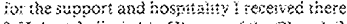

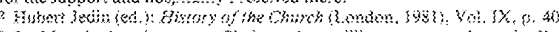

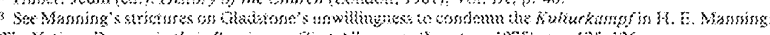

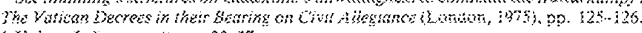

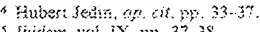

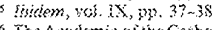

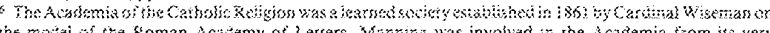

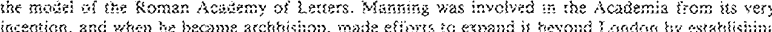

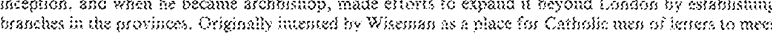

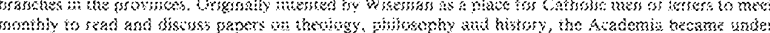

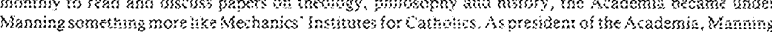

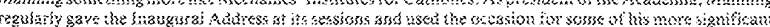

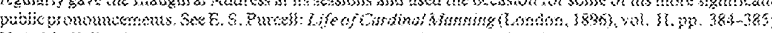

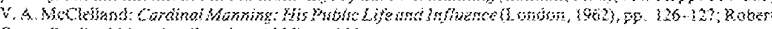

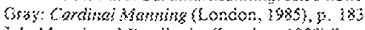

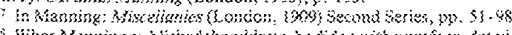

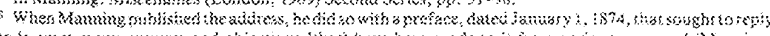

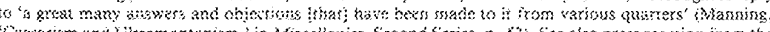

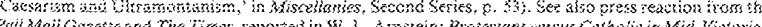

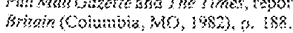

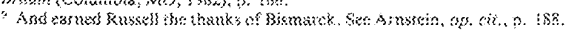

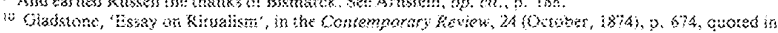

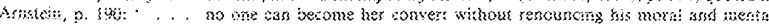

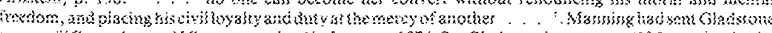

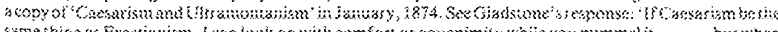

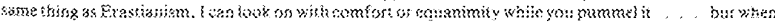




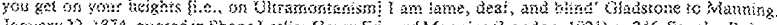

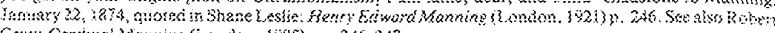

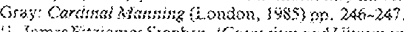

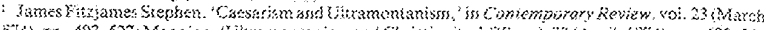

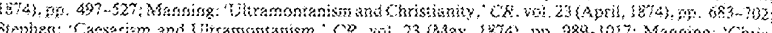

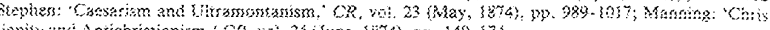

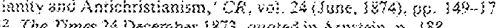

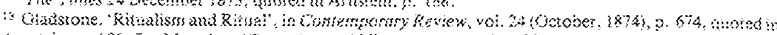

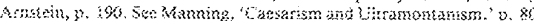

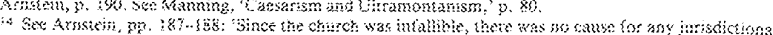

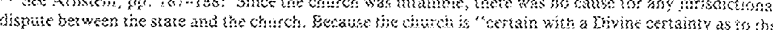

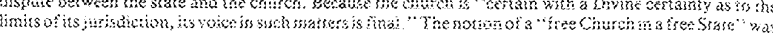

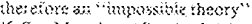

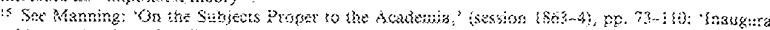

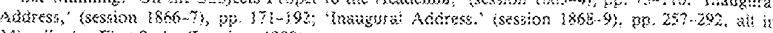

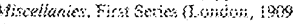

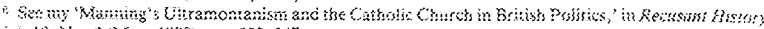

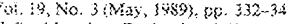

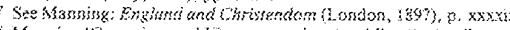

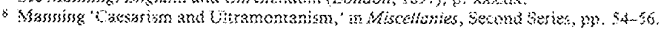

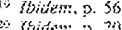

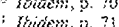

raidem, 76

shisem, on

2.s thisem, 13

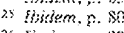

20. Yutsem. p. 82

Ibidem o. e.

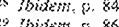

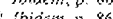

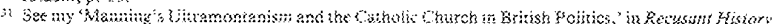
secting

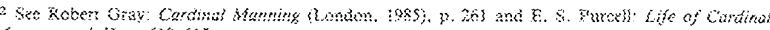

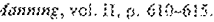

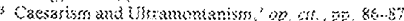

Wiuten, o.

s) stidem; 9 ? 9 ?

Iticiem, 8 . $8 \mathrm{x}$

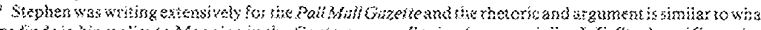

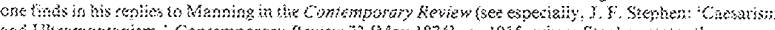

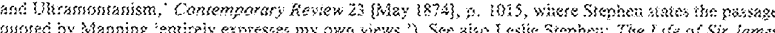

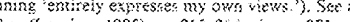

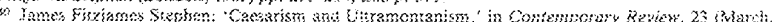

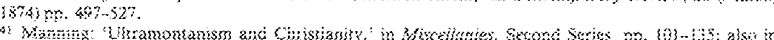

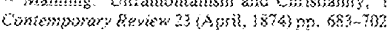

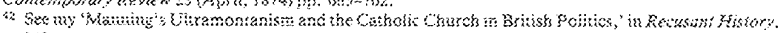

3. 340 .

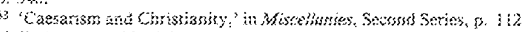

Mbitem, gys.:22-32t

(7)

bivets. p. : :

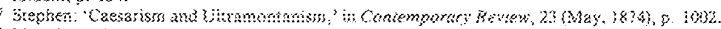

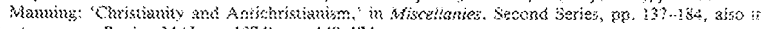

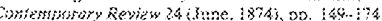

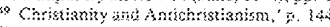

Shisem. F. 2??

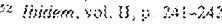

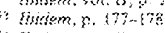

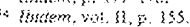

\section{MANNING AS POLITICIAN}

\author{
by DERMOT QUNW
}

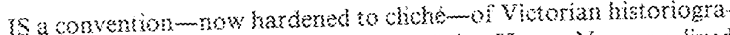

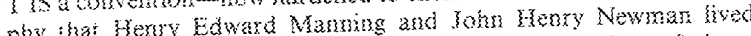

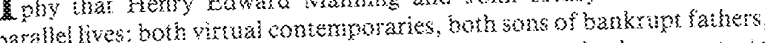

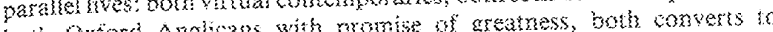
both Oxtord Anghears with promise Rome, both ascetics, both Cardiraks. Eually convento

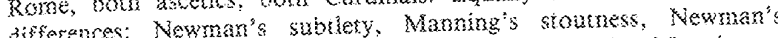

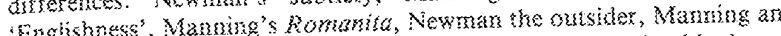

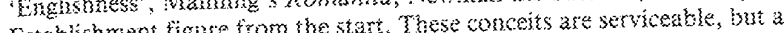

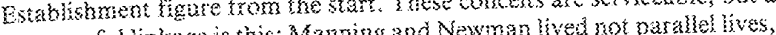
but pastuoxical unes, the yaradox being that each in a rense, wed the other man's life. Consider kow each beveloped in unimagned ways. Newman was one of the most private non of his aky. To a temperanem already solitury was adied the isolation of conversion, then the tonetiness of falure, finaly the reailsation that he represented onky a muority an a Mamboyanty Ultramontane chum. Yet Nexrman was never left alone

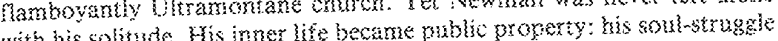

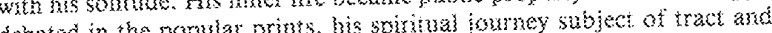

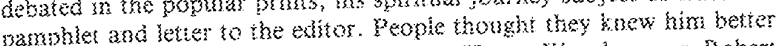

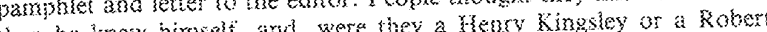
than he knew himse?

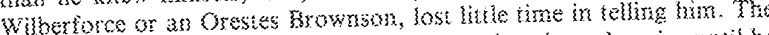
boumaries of a decsnt interiority were crosed agsin and again, antil he becarse jcon, symbot, Everyman's Newrmas3.

Sun wat the parabox of one cordinat with the of her it woud be said

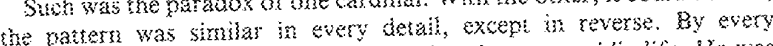

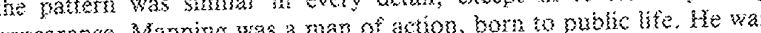

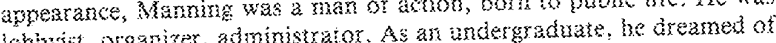
lobbyist, organizer, abministrator. As an andergraduate, he dreaned of

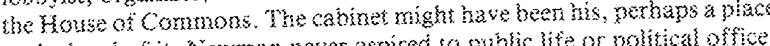

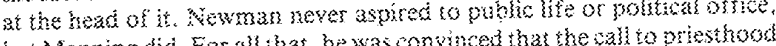

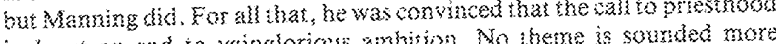

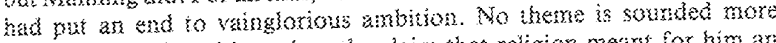

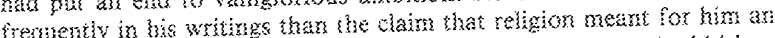

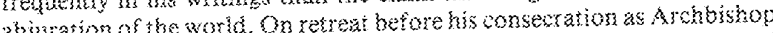
of Westrinstar, he "evicwed his hick At the age of 24 , he had possessed

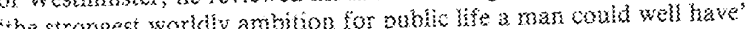

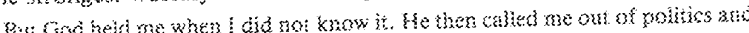

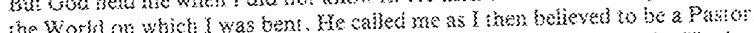

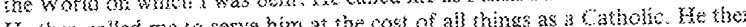

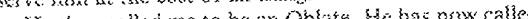
waled we to be as grest. be then me to the reatest cross of my bife and to the preatest separction thom the world.

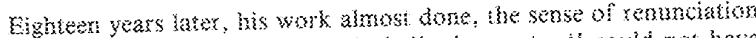
wan umanged. On becoming a catholit, he srote. "I coukd not have 